\title{
Identifying the Roles of Interleukin-13 in Childhood Asthma
}

\author{
Kamleshun Ramphul \\ Department of Pediatrics, Xinhua Hospital Affiliated to Shanghai Jiao Tong University School of Medicine, \\ Shanghai, China \\ Email: adramphul@hotmail.com
}

Received 19 April 2014; revised 26 May 2014; accepted 9 June 2014

Copyright (C) 2014 by author and OALib.

This work is licensed under the Creative Commons Attribution International License (CC BY). http://creativecommons.org/licenses/by/4.0/

c) $\underset{\mathrm{EY}}{\mathrm{i}}$ Open Access

\begin{abstract}
Asthma is a chronic inflammatory disease of the airways manifested by reversible airflow obstruction and airway hyperresponsiveness. While recent research has mapped several genes as possible factors predisposing to asthma, interleukin-13 remains one of the most commonly found genes in various populations. IL-13 is a pleiotropic TH2 cytokine which has been linked to cause an increase in goblet cell differentiation, activation of fibroblasts, elevation of bronchial hyperresponsiveness and switching of $B$ cell antibody from IgM to IgE. The aim of this review is to study and identify the three main single-nucleotide polymorphisms of IL-13 (IL13 R130Q, IL-13R $\alpha$ 1 and IL-13 A2044G) that have been linked to asthma in children, and to understand their respective roles in the pathogenesis of this disease.
\end{abstract}

\section{Keywords}

Asthma, Interleukin 13, Children

Subject Areas: Medical Genetics, Women's Health

\section{Introduction}

Asthma is one of the most common chronic respiratory diseases in childhood, characterized by the reversible airflow obstruction due to chronic inflammation of the airways [1]. It is thought to be caused by a combination of genetic and environmental factors [2] and the prevalence of this disease has been reported as increasing globally [3] [4]. Asthma presents as recurrent episodes of wheezing, chest tightness, coughing and breathlessness [5] which can be triggered by exposures to environmental factors such as allergens, pharmacological agents and pollutants as well as infectious sources or stimuli such as viruses. In the last ten years, the analysis of single-nuc- 
leotide polymorphisms (SNPs) has become the newest approach in the detection and localization of the genetic determinants of asthma [6] [7] and we have been able to identify several genes predisposing to asthma in both adults and children.

Interleukin-13 is one of the most frequently reported genes in the predisposition of asthma in the whole population, irrespective of age, gender and ethnic background. There are different hypotheses that CD4+ T cells are the primary orchestrators of the immune response corresponding to the pathogenesis of asthma and IL-13 is one of the cytokines involved. Human IL-13 is a 17-kDa glycoprotein cloned mainly from activated T cells [8] and the gene is located on chromosome $5 q 31$ which also codes for other factors linked to airway responsiveness, total serum IgE such as IL-4, IL-3, IL-5 and granulocyte-macrophage colony stimulating factor [9]-[14]. Recent studies on human subjects and animals have indicated a critical role of IL-13 in the pathogenesis of allergic disease in the whole population and can cause an increase in goblet cell differentiation, activation of fibroblasts, elevation of bronchial hyperresponsiveness and switching of B cell antibody from IgM to IgE [15]-[19]. Our main aim is to identify the different single-nucleotide polymorphisms of IL-13 which predisposes asthmatic children.

\section{IL13 R130Q}

IL13 R130Q is one of the single nucleotide polymorphisms of IL-13 that has been reported as a risk factor for asthma in children. R130Q (rs 20541) is a coding SNP in exon 4 (Arg $130 \mathrm{Gln}$ ) and the $130 \mathrm{Gln}$ substitution can result in signal transducer and activation of transcription phosphorylation in monocytes. Zitnik S.E. et al. studied the occurance of R130Q in children suffering from atopic dermatitis up to 4-year of age and their level of total IgE. In their research they found statistical evidence that IL-13 R130Q allele was related to slightly elevated total IgE levels compared to the heterozygotes and was a risk factor in the development of allergic dermatitis [20]. In 2008 Chan et al. conducted a research with 18SNPs in Chinese asthmatic children and only R130Q showed a significant association with plasma total $\operatorname{IgE}(P=0.035)$ [21] supporting the results published by Hunninghake et al. [22] and Leung et al. [23]. Recent research conducted in middle China by Wu X. et al. found significant differences of IL-13 R130Q in genotype and frequency distributions between the asthma group and the control group. They also noted that the A allele of IL-13 R130Q was significantly associated with an increased risk of asthma in the children from middle China (odds ratio [OR] $=1.59,95 \%$ confidence interval $[\mathrm{CI}] 1.20-2.09, P=$ 0.0010) [24]. A meta-analysis performed by Cui et al. in 2012 provided evidence that the R130Q polymorphism in IL-13 is a risk factor of asthma. In the subgroup analysis by ethnicity, the significant association was also found in Caucasians (heterozygote comparison: $\mathrm{OR}=1.37,95 \%$ CI $1.01-1.85$; and dominant model: $\mathrm{OR}=1.38$, 95\% CI 1.04 - 1.83, respectively) but not in Asians [25].

\section{IL-13 A2044G}

IL-13 A2044G (rs20541) is another commonly seen polymorphism of interleukin 13. For the general population a meta-analysis conducted by Wei et al. in 2012 indicated a significant association between IL13+2044A/G polymorphism and asthma risk (OR $=1.18,95 \%$ CI $1.08-1.28, P=0.0002)$. In the subgroup analysis by ethnicity, there were significant associations between IL13+2044A/G polymorphism and asthma risk in Asians $(\mathrm{OR}=$ 1.19, 95\% CI $1.04-1.36, P=0.01)$ and Caucasians (OR $=1.22$, 95\% CI $1.06-1.40, P=0.005)$ but not in African Americans [26]. While the amount of research for the pediatric population for this particular polymorphism is limited, Liu et al. proved that A2044G is closely associated with asthma in children of Chinese Han nationality $\left(\chi^{2}=13.112, P=0.0001\right)$. IL-13 A2044G is associated with a high eosinophil count [22] [27]. RANTES G-28C is located in the promoter region and it may enhance the transcriptional activity resulting in overexpression in lung cells. This change may lead to an increase in recruitment of neurtrophils and eosinophils in the airways, causing inflammation [28] [29]. RANTES G-28C also predisposes to airway obstruction [28]. Liu et al. found a relationship between the combined roles of IL-13 A2044G and RANTES G-28C in children suffering from asthma in China. the frequency of IL-13 A2044G A/A and RANTES G-28C G/G in the asthma group was significantly higher than in the control group (odds ratio $[\mathrm{OR}]=2.59, P=0.0001$; $\mathrm{OR}=3.00, P=0.0001$, respectively). Previous reports have shown that IL13-A2044G and RANTES G-28C were associated with an increased risk of asthma in Asian populations [30] [31]. IL13-A2044G can modify the primary structure of protein of IL-13 which is more active than WT IL-13 [32] [33]. They also suggested that the airway muscle cells and epithelial cells can overexpress RANTES by regulation of the mutant IL-13, and RANTES is greatly over ex- 
pressed through interaction between the mutant IL-13 and RANTES G-28C. Carriers of both IL-13 A2044G A/A and RANTES G-28C G/G had a more significant risk for developing asthma than those with only a single polymorphism.

\section{IL-13R $\alpha 1$}

Interleukin-13 Receptor alpha 1 (IL-13R $\alpha 1$ ) is thought to have a major contribution to the development and maturation of cells of the immune system and it also participates in various immune responses. Recent research by Dhakal et al. suggested that IL-13R $\alpha 1$ is expressed on the M2 but not on the M1 subset of macrophages and can specifically heterodimerize with the IL-4R $\alpha$ chain to form a type II receptor [34]. Kim et al. studied the genegene interaction between IL-13 and IL-13R $\alpha 1$ and their association with total IgE in asthmatic children in Korea. According to their research, the risk alleles for asthma were IL-13 A1512C, IL-13 C1112T and IL-13 R $\alpha 1$ (A1398G) which showed an increased total IgE ( $P=0.012,0.015$ and 0.017 , respectively). They also performed a gene-gene interaction between risk alleles and it was associated with higher total IgE in children with atopic asthma $(P=0.002,0.010)$ suggesting that IL-13 polymorphisms and IL-13R $\alpha 1$ may interact to enhance IgE production and thus may have an important role in the pathogenesis of asthma [35]. Various reports for the general populations have shown the association of atopic asthma with IL-13 R $\alpha 1$ [36]-[40]. However the number of reports for the pediatric population is limited but promising.

\section{Discussion}

Asthma is a common clinical syndrome resulting from several factors such as immunity, environment and heredity. Genetic predisposition is probably caused by a characteristic pattern of polymorphism in multiple genes involved in the regulation of the allergic reaction and the identification of these polymorphism patterns can be of predictive use for childhood asthma diagnosis. In our review we found that IL13 R130Q is one of the most commonly found polymorphism of interleukin-13 found in children from asthma. IL-13 A2044G can predispose children to asthma and carriers of both IL-13 A2044G A/A and RANTES G-28C G/G had a more significant risk for developing asthma than those with only a single polymorphism. IL-13R $\alpha 1$ is a novel aspect of research which has not been fully explored in the pediatric population. It has shown close association with the disease in adult asthmatics and asthmatic children from Korea.

\section{Conclusion}

While recent research has mapped several genes as possible factors predisposing to asthma, interleukin-13 remains one of the most commonly found genes in various populations. Further research involving interleukin-13 will help us understand the pathogenesis and the polymorphisms predisposing to asthma in children even better.

\section{Disclosure}

The authors declare no conflicts of interest in this work.

\section{References}

[1] Accordini, S., Corsico, A., Cerveri, I., Gislason, D., Gulsvik, A., Janson, C., et al. (2008) Thesocio-Economic Burden of Asthma Is Substantial in Europe. Allergy, 63, 116-124. http://dx.doi.org/10.1111/j.1398-9995.2007.01523.X

[2] Sengler, C., Lau, S., Wahn, U. and Nickel, R. (2002) Interactions between Genes and Environmental Factors in Asthma and Atopy: New Developments. Respiratory Research, 3, 7. http://dx.doi.org/10.1186/rr179

[3] Lee, Y.L., Lin, Y.C., Hwang, B.F. and Guo, Y.L. (2005) Changing Prevalence of Asthma in Taiwanese Adolescents: Two Surveys 6 Years Apart. Pediatric Allergy and Immunology, 16, 157-164. http://dx.doi.org/10.1111/j.1399-3038.2005.00211.x

[4] Maziak, W., Behrens, T., Brasky, T.M., Duhme, H., Rzehak, P., et al. (2003) Are Asthma and Allergies in Children and Adolescents Increasing? Results from ISAAC Phase I and Phase III Surveys in Munster, Germany. Allergy, 58, 572-579. http://dx.doi.org/10.1034/j.1398-9995.2003.00161.x

[5] Wills-Karp, M. (1999) Immunologic Basis of Antigeninduced Airway Hyperresponsiveness. Annual Review of Immunology, 17, 255-281. http://dx.doi.org/10.1146/annurev.immunol.17.1.255

[6] Denham, S., Koppelman, G.H., Blakey, J., Wjst, M., Ferreira, M.A., Hall, I.P., et al. (2008) Meta-Analysis of Genome- 
Wide Linkage Studies of Asthma and Related Traits. Respiratory Research, 9, 38. http://dx.doi.org/10.1186/1465-9921-9-38

[7] Zhang, Y., Zhang, J., Huang, J., Li, X., He, C., Tian, C., et al. (2010) Polymorphisms in the Transforming Growth Factor-Beta1 Gene and the Risk of Asthma: A Meta-Analysis. Respirology, 15, 643-650. http://dx.doi.org/10.1111/j.1440-1843.2010.01748.x

[8] Zurawski, G. and de Vries, J. (1994) Interleukin-13, an Interleukin-4 Like Cytokine That Acts on Monocytes and B Cells but Not T-Cells. Immunology Today, 15, 19-26. http://dx.doi.org/10.1016/0167-5699(94)90021-3

[9] Baldini, M., Lohman, I.C., Halonen, M., Erickson, R.P., Holt, P.G. and Martinez, F.D. (1999) A Polymorphism in the 5' Flanking Region of the CD14 Gene Is Associated with Circulating Soluble CD14 Levels and with Total Serum Immunoglobulin E. American Journal of Respiratory Cell and Molecular Biology, 20, 976-983. http://dx.doi.org/10.1165/ajrcmb.20.5.3494

[10] Kawakami, Y. (1992) Genetic Background of Bronchial Asthma. Nihon Kyobu Shikkan Gakkai Zasshi, 30, 1-4.

[11] Marsh, D.G., Neely, J.D., Breazeale, D.R., Ghosh, B., Freidhoff, L.R., Ehrlich-Kautzky, E., et al. (1994) Linkage Analysis of IL4 and Other Chromosome 5q31.1 Markers and Total Serum Immunoglobulin E Concentrations. Science, 264, 1152-1156. http://dx.doi.org/10.1126/science.8178175

[12] Postma, D.S., Bleecker, E.R., Amelung, P.J., Holroyd, K.J., Xu, J., Panhuysen, C.I., et al. (1995) Genetic Susceptibility to Asthma-Bronchial Hyperresponsiveness Coinherited with a Major Gene for Atopy. New England Journal of Medicine, 333, 894-900. http://dx.doi.org/10.1056/NEJM199510053331402

[13] Xu, J., Levitt, R.C., Panhuysen, C.I., Postma, D.S., Taylor, E.W., Amelung, P.J., et al. (1995) Evidence for Two Unlinked Loci Regulating Total Serum IgE Levels. American Journal of Human Genetics, 57, 425-430.

[14] Noguchi, E., Shibasaki, M., Arinami, T., Takeda, K., Maki, T., Miyamoto, T., et al. (1997) Evidence for Linkage between Asthma/Atopy in Childhood and Chromosome 5q31-q33 in a Japanese Population. American Journal of Respiratory and Critical Care Medicine, 156, 1390-1393. http://dx.doi.org/10.1164/ajrccm.156.5.9702084

[15] Grunig, G., Warnock, M., Wakil, A.E., Venkayya, R., Brombacher, F., Rennick, D.M., et al. (1998) Requirement for IL-13 Independently of IL-4 in Experimental Asthma. Science, 282, 2261-2263. http://dx.doi.org/10.1126/science.282.5397.2261

[16] Wills-Karp, M., Luyimbazi, J., Xu, X.Y., Schofield, B., Neben, T.Y., Karp, C.L., et al. (1998) Interleukin-13: Central Mediator of Allergic Asthma. Science, 282, 2258-2260. http://dx.doi.org/10.1126/science.282.5397.2258

[17] Huang, S.K., Xiao, H.Q., Kleine-Tebbe, J., Paciotti, G., Marsh, D.G., Lichtenstein, L.M., et al. (1995) IL-13 Expression at the Sites of Allergen Challenge in Patients with Asthma. The Journal of Immunology, 155, 2688-2694.

[18] Pawankar, R.U., Okuda, M., Hasegawa, S., Suzuki, K., Yssel, H., Okubo, K., et al. (1995) Interleukin-13 Expression in the Nasal Mucosa of Perennial Allergic Rhinitis. American Journal of Respiratory and Critical Care Medicine, 152, 2059-2067. http://dx.doi.org/10.1164/ajrccm.152.6.8520776

[19] Katagiri, K., Itami, S., Hatano, Y. and Takayasu, S. (1997) Increased Levels of IL-13 mRNA, but Not IL-4 mRNA, Are Found in Vivo in Peripheral Blood Mononuclear Cells (PBMC) of Patients with Atopic Dermatitis (AD). Clinical Experimental Immunology, 108, 289-294. http://dx.doi.org/10.1046/j.1365-2249.1997.d01-1015.x

[20] Zitnik, S.E., Rüschendorf, F., Müller, S., Sengler, C., Lee, Y.A., Griffioen, R.W., Meglio, P., Wahn, U., Witt, H. and Nickel, R. (2009) IL13 Variants Are Associated with Total Serum IgE and Early Sensitization to Food Allergens in Children with Atopic Dermatitis. Pediatric Allergy and Immunology, 20, 551-555. http://dx.doi.org/10.1111/j.1399-3038.2008.00815.x

[21] Chan, I.H., Tang, N.L., Leung, T.F., Huang, W., Lam, Y.Y., Li, C.Y., Wong, C.K., Wong, G.W. and Lam, C.W. (2008) Study of Gene-Gene Interactions for Endophenotypic Quantitative Traits in Chinese Asthmatic Children. Allergy, 63, 1031-1039.

[22] Hunninghake, G.M., Soto-Quiros, M.E., Avila, L., Su, J., Murphy, A., Demeo, D.L., et al. (2007) Polymorphisms in IL13, Total IgE, Eosinophilia, and Asthma Exacerbations in Childhood. Journal of Allergy and Clinical Immunology, 120, 84-90. http://dx.doi.org/10.1016/j.jaci.2007.04.032

[23] Leung, T.F., Tang, N.L., Chan, I.H., Li, A.M., Ha, G. and Lam, C.W. (2001) A Polymorphism in the Coding Region of Interleukin-13 Gene Is Associated with Atopy but Not Asthma in Chinese Children. Clinical Experimental Allergy, 31, 1515-1521. http://dx.doi.org/10.1046/j.1365-2222.2001.01212.X

[24] Wu, X., Li, Y., Chen, Q., Chen, F., Cai, P., Wang, L. and Hu, L. (2010) Association and Gene-Gene Interactions of Eight Common Single-Nucleotide Polymorphisms with Pediatric Asthma in Middle China. Journal of Asthma, 47, 238-244. http://dx.doi.org/10.3109/02770900903509099

[25] Cui, L., Jia, J., Ma, C.F., Li, S.Y., Wang, Y.P., Guo, X.M., Li, Q., Yu, H.B., Liu, W.H. and Gao, L.B. (2012) IL-13 Polymorphisms Contribute to the Risk of Asthma: A Meta-Analysis. Clinical Biochemistry, 45, 285-288. http://dx.doi.org/10.1016/j.clinbiochem.2011.12.012 
[26] Nie, W., Liu, Y.G., Bian, J.R., Li, B. and Xiu, Q.Y. (2013) Effects of Polymorphisms -1112C/T and +2044A/G in Interleukin-13 Gene on Asthma Risk: A Meta-Analysis. PLoS One, 8, Article ID: e56065. http://dx.doi.org/10.1371/journal.pone.0056065

[27] Choi, W.A., Kang, M.J., Kim, Y.J., Seo, J.H., Kim, H.Y., Kwon, J.W., et al. (2012) Gene-Gene Interactions between Candidate Gene Polymorphisms Are Associated with Total IgE Levels in Korean Children with Asthma. Journal of Asthma, 49, 243-252. http://dx.doi.org/10.3109/02770903.2012.660294

[28] Martinez, F.D., Wright, A.L., Taussig, L.M., Holberg, C.J., Halonen, M. and Morgan, W.J. (1995) Athma and Wheezing in the First Six Years of Life. The Group Health Medical Associates. The New England Journal of Medicine, 332, 133-138. http://dx.doi.org/10.1056/NEJM199501193320301

[29] Sohn, M.H., Kim, S.H., Kim, K.W., Jee, H.M., Park, H.S. and Kim, K.E. (2008) RANTES Gene Promoter Polymorphisms Are Associated with Bronchial Hyperresponsiveness in Korean Children with Asthma. Lung, 186, 37-43. http://dx.doi.org/10.1007/s00408-007-9049-3

[30] Yang, H., Dong, H., Dai, Y. and Zheng, Y. (2011) Association of Interleukin-13 C-1112T and G+2044A Polymorphisms with Asthma: A Meta-Analysis. Respirology, 16, 1127-1135. http://dx.doi.org/10.1111/j.1440-1843.2011.02021.x

[31] Fang, Q., Wang, F. and Zhao, D. (2010) Association between Regulated upon Activation, Normal T Cells Expressed and Secreted (RANTES) -28C/G Polymorphism and Asthma Risk-A Meta-Analysis. International Journal of Medical Sciences, 7, 55-61. http://dx.doi.org/10.7150/ijms.7.55

[32] Vladich, F.D., Brazille, S.M., Stern, D., Peck, M.L., Ghittoni, R. and Vercelli, D. (2005) IL-13 R130Q, a Common Variant Associated with Allergy and Asthma, Enhances Effector Mechanisms Essential for Human Allergic Inflammation. Journal of Clinical Investigation, 115, 747-754. http://dx.doi.org/10.1172/JCI200522818

[33] Chu, Y., Hua, L., Liu, Q. and Bao, Y. (2012) A Common Variant Associated with Asthma, Interleukin 13 R130Q, Promotes the Production of IgE. International Journal of Immunogenetics, 39, 308-313. http://dx.doi.org/10.1111/j.1744-313X.2012.01091.x

[34] Dhakal, M., Hardaway, J.C., Guloglu, F.B., Miller, M.M., Hoeman, C.M., Zaghouani, A.A., Wan, X., Rowland, L.M., Cascio, J.A., Sherman, M.P. and Zaghouani, H. (2014) IL-13R $\alpha 1$ Is a Surface Marker for M2 Macrophages Influencing Their Differentiation and Function. European Journal of Immunology, 44, 842-855. http://dx.doi.org/10.1002/eji.201343755

[35] Kim, H.B., Lee, Y.C., Lee, S.Y., Jung, J., Jin, H.S., Kim, J.H., Kim, B.S., Kang, M.J., Jang, S.O., Kim, J., Kimm, K., Shin, E.S., Lee, S.G. and Hong, S.J. (2006) Gene-Gene Interaction between IL-13 and IL-13Ralpha1 Is Associated with Total IgE in Korean Children with Atopic Asthma. Journal of Human Genetics, 51, 1055-1062. http://dx.doi.org/10.1007/s10038-006-0061-X

[36] Ahmed, S., Ihara, K., Sasaki, Y., Nakao, F., Nishima, S., Fujino, T. and Hara, T. (2000) Novel Polymorphism in the Coding Region of the IL-13 Receptor Alpha' Gene: Association Study with Atopic Asthma in the Japanese Population. Experimental and Clinical Immunogenetics, 17, 18-22. http://dx.doi.org/10.1159/000019120

[37] Rothenberg, M.E., Wen, T., Shik, D., Cole, E.T., Mingler, M.M. and Munitz, A. (2011) IL-13 Receptor $\alpha 1$ Differentially Regulates Aeroallergen-Induced Lung Responses. The Journal of Immunology, 187, 4873-4880. http://dx.doi.org/10.4049/jimmunol.1004159

[38] Redpath, N.T., Xu, Y., Wilson, N.J., Fabri, L.J., Baca, M., Andrews, A.E., Braley, H., Lu, P., Ireland, C., Ernst, R.E., Woods, A., Forrest, G., An, Z., Zaller, D.M., Strohl, W.R., Luo, C.S., Czabotar, P.E., Garrett, T.P., Hilton, D.J., Nash, A.D., Zhang, J.G. and Nicola, N.A. (2013) Production of a Human Neutralizing Monoclonal Antibody and Its Crystal Structure in Complex with Ectodomain 3 of the Interleukin-13 Receptor $\alpha 1$. Biochemical Journal, 451, 165-175. http://dx.doi.org/10.1042/BJ20121819

[39] Martinez-Nunez, R.T., Louafi, F. and Sanchez-Elsner, T. (2011) The Interleukin 13 (IL-13) Pathway in Human Macrophages Is Modulated by MicroRNA-155 via Direct Targeting of Interleukin 13 Receptor Alpha1 (IL13Ralpha1). The Journal of Biological Chemistry, 286, 1786-1794. http://dx.doi.org/10.1074/jbc.M110.169367

[40] Munitz, A., Brandt, E.B., Mingler, M., Finkelman, F.D. and Rothenberg, M.E. (2008) Distinct Roles for IL-13 and IL-4 via IL-13 Receptor Alpha1 and the Type II IL-4 Receptor in Asthma Pathogenesis. Proceedings of the National Academy of Sciences of the United States of America, 105, 7240-7245. http://dx.doi.org/10.1073/pnas.0802465105 